Open Access

\title{
The scope of coaching in the context of organizational change
}

Angelina Rosha and Natalja Lace

*Correspondence: natalja.lace@rtu.lv
Riga Technical University, 6
Kalnciema Street, Riga LV-1007, Latvia

\section{Springer}

\begin{abstract}
The aim of this paper is to explore the scope of coaching in the context of organizational change considering peculiar issues associated with the use of coaching in Latvia and Lithuania.

This two-stage study seeks to answer the following research questions. How is coaching defined? What is the aim of coaching? Who are involved in coaching? What coaching outcomes are expected? During the first stage, the definitions of coaching are extracted from the literature and analyzed to identify the distinctive features of coaching. During the second stage, the experts are interviewed to explore the views of practitioners in coaching about a place of coaching in organizations. Literature review, content analysis and comparative analysis are used for the purposes of this study. Triangulation of research results is obtained through cross verification from two sources.

A total of 41 definitions of coaching were extracted from the literature and taken for analysis. Based on the established criteria for selection, nine experts participated in an interview.

As a result, content analysis and comparative analysis have revealed that coaching is defined as a regular, synergetic, learning and development, goal-oriented process. Facilitation is a primary aim of coaching. Coaching is more beneficial for people who provide decisions. Achieved results and personal growth is considered as the key expected coaching outcomes. Coaching provides greater goal clarity, better alignment with the roles in the organization. However, the possible threats and challenges, such as stereotype and misunderstanding, lack of systematic approach to coaching engagements as well as its alignment with organizational change needs, have also been detected. It is difficult to explain how effective coaching can be because coaching is not homogeneous and it is difficult to measure the results of coaching.

Keywords: Coaching, Organizational change, EU New Member States
\end{abstract}

\section{Background}

Nowadays, organizations operate in the dynamic, competitive and challenging global environment (Allen et al. 2013). As the global business environment continues to be uncertain, complex and ambiguous, organizations should be ready to initiate and manage change (Amagoh 2008). Change affects all organisations (By 2005). Dynamics in both external and internal environment can trigger a requirement for change (Spector 2007). The impact of external environment and the shift between life cycle stages can cause organisational change. Burnes (2004) defines organizational change 
as 'an ever-present' form of organizational life that focuses on both the performance of the whole organisation and day-to-day operations.

Organizations respond to the trigger events in different ways: focusing on new behavioral patterns or enhancing the financial or technological effectiveness. It is worth mentioning that effective change involves both content - 'what is being changed' and process - 'how are the changes being implemented' (Spector 2007).

Rank et al. (2004) believe that creativity, innovation and initiative facilitate organizational change. Open innovation is considered as the latest corporate philosophy which integrates internal experience and capabilities and external knowledge and competence to accelerate the development of organization (Patra and Krishna 2015). Corte et al. (2015) argue that customers are a valuable source for innovation because they can contribute to organization's innovative process by sharing their opinions and expressing their ideas.

To cope with the constraints on changes in the business environment, it is necessary to develop new knowledge and skills as well as the ability to apply integrated ways of thinking in a short period of time. Change demands from organizations the ability to manage change, to develop and apply new knowledge and skills. This is especially important in the current period of increasing globalization, deregulation and the high growth pace of technological innovation (By 2005). Ambiguity, uncertainty and inconsistency of business environment provide the impetus for organizational learning, diversity and renewal (Graetz and Smith 2010).

Change can also cause a number of problems. Individuals need to achieve goals and develop, at the same time, they have to deal with the troubles caused by change. In the period of organizational change, people face with the need to develop and carry out the established goals, and at the same time, they need to deal with organizational turbulence (Grant 2014). Therefore, there is a need to facilitate people in organizations in the period of change to enhance goal attainment, encourage development and support them to tackle change problems.

There are a variety of practices, including coaching, that facilitate people providing them support and accelerating the process of setting and achieving work-related goals (Megginson \& Boydell 1979, Grant 2014). According to the opinions of different scholars (Kelley et al. 2005; Connor and Pokora 2007; Garvey et al. 2009; Cox et al. 2011; Audet and Couteret 2012; Cox 2013; Bozer et al. 2013; Page and de Haan 2014), coaching can promote sustainable organizational change.

However, coaching in EU New Member States is not a widespread practice and is not yet studied thoroughly. 2012 ICF Global Coaching Study demonstrated a very diverse distribution in professional coaches across the globe. Comparing to Western Europe where the ratio of coaches per 1 million population is more than 44 , the ratio of coaches per 1 million population in Eastern Europe is about eight.

Therefore, the aim of this paper is to explore the scope of coaching that is the extent of the subject matter in the context of organizational change considering peculiar issues associated with the use of coaching in Latvia and Lithuania.

The paper seeks to address the following research questions:

RQ 1 How is coaching defined?

RQ 2 What is the aim of coaching? 
RQ 3 Who are involved in coaching?

RQ 4. What are expected coaching outcomes?

For the purposes of this study, the authors employed two-step research: content analysis of both coaching definitions extracted from the literature and experts' interview with subsequent comparative analysis of the obtained results.

\section{The nature of coaching: literature review}

Coaching is becoming increasingly popular in today's business environment (Hamlin et al. 2011); more and more organisations are using coaching as a means of improving performance, developing skills and capability, facilitating leadership development, as well as career managing. CIPD's (Chartered Institute of Personnel Development) Coaching Climate survey report (2011) proves this fact. As it was stated, compared with CIPD coaching survey 2009, the number of respondents who reported that coaching is focused on improving good performance increased from a quarter to almost half. More than $60 \%$ of respondents reported that the purpose of coaching is to aid leadership development, this is three times more compared to 2009. Almost a quarter of respondents always focus on improving personal effectiveness delivering coaching assignments. Supporting career transition is also among key areas of coaching agenda, $10 \%$ of respondents always and $44 \%$ frequently address this issue in coaching agenda.

Vidal-Salazar et al. (2012) offer empirical evidence of the positive effect of coaching on organisational change. The results of Baron and Morin (2010) study suggest that coaching can have a real practical impact on the development of strong self-efficacy that enables to perform tasks more effectively. As a management developmental activity, coaching promotes organisational change and leads to sustainability (Bozer et al. 2013). As an interactive form of organisational learning and leadership development (De Haan et al. 2011, Page and de Haan 2014), coaching enhances the executive's behavioral change through self-awareness and learning, and thereby contributes to individual and organizational success (Bozer et al. 2013, Berg \& Karlsen 2011). Behavioural change within the organisational change opens a number of opportunities for coaching as a tool in implementing and sustaining change (Stober 2008). Coaching can be used to encourage teamworking of existing groups, develop newly-formed teams, improve the communicating skills of team leaders and develop cross boundary teams (Connor and Pokora 2007). Coaching promotes the development of entrepreneurial skills through facilitating implementation of the own strategic vision (Audet and Couteret 2012). Coaching facilitates moving beyond innovative technologies from finding ideas and developing them to linking innovations to the company's strategy and the markets for what they have done (Kelley et al. 2005).

During its long history, coaching has been associated with individuals' professional and personal goals attainment, performance improvement, and personal potential enhancement (Garvey et al. 2009 Garvey 2011). The goal-oriented nature of coaching lies in its historical roots. At the same time psychology, psychotherapy, education, sport and business influenced the development of coaching (Stojnov and Pavlovic 2010). Incorporated range of therapeutic and personal development approaches enable to diversify coaching and expand its implementation as developmental practice. The Dublin declaration on coaching (2008) proposed the recognition of the multidisciplinary roots 
of coaching and recommended to affirm the nature of coaching as a specific synthesis of "a range of disciplines that creates a new and distinctive value to individuals, organizations and society".

Cox et al. (2011) investigated theoretical approaches genres and contexts of coaching. They ascertain a tight relationship between cognitive-behavioural approach and genres and contexts of coaching used in organisational context, such as, for instance, executive and leadership coaching, team coaching. They argue that coaching adopted the cognitive-behavioural approach focuses on the replacement of dysfunctional thought patterns with more adaptive versions. As a result, executives as well as managers learn to become efficient in managing their emotions, maintaining an appropriate level of self-confidence and developing high level of interpersonal and communication skills (Cox et al. 2011).

Although coaching has become incredibly popular, there is still a lot of uncertainty and vagueness around what coaching is really about (Ives 2008). There is no general agreement on the definition of coaching among scholars and practitioners (Ladyshewsky 2010) and no coherent approach to define coaching (Passmore and FilleryTravis 2011). The essence of a 'typical' coaching intervention still remains difficult to define (Kempster and Iszatt-White 2013). Bond and Seneque (2013) have stated that early definitions of coaching were focused on the improvement of individual and organizational performance while more recent definitions have defined coaching as a process emphasized a stronger link with learning and development.

\section{Coaching in Latvia and Lithuania}

Coaching is still a relatively new professional field in Latvia and Lithuania. Global Coaching Survey 2008/2009 defined the life-cycle stage of coaching for each European country. Under the Survey, coaching in Latvia was in pre-introduction phase while coaching in Lithuania was in transition between introduction and growth stages. Based on the overview of the answers, it was stated that in Latvia and Lithuania people do not fully understand the essence of coaching and tend to confuse coaching with consulting.

The online study has been conducted by the authors to investigate the current state of affairs in the field of coaching in Latvia and Lithuania with special emphasis on the use of coaching for organisational purposes. The observation of the current situation is presented in the table (see Table 1).

While gathering information, it was revealed that the interest in coaching among organisations is growing. The increasing number of leaders and managers participating in different coaching events proves this. The surveys in 2011 and 2013 conducted by TNS, demonstrate positive dynamics of the topic development. The number of top managers who are aware of coaching is increased by $5 \%$ in 2013. The comparison of the results of two surveys about executives' perception of coaching shows that there is a rise in opinion that coaching can contribute to the achievement of the organization business objectives. However, the view on coaching as a fashion trend is increased as well. The author of the TNS survey considers that this is explained by the fact that a considerable number of company executives ( $45 \%$ ) still do not know what coaching is.

Coaching in Latvia and Lithuania is viewed from different perspectives - as means of achieving one's individual goals, business targets, implementing change management, 
Table 1 Implementation of coaching in Latvia and Lithuania

\begin{tabular}{|c|c|c|}
\hline Means of implementation & Latvia & Lithuania \\
\hline $\begin{array}{l}\text { International coaching } \\
\text { organisations }\end{array}$ & $\begin{array}{l}\text { International Coach Federation Latvia } \\
\text { Chapter; European Coach Federation }\end{array}$ & $\begin{array}{l}\text { International Coach Federation } \\
\text { Lithuania Chapter; International Coach } \\
\text { and Trainer Association (ICTA) }\end{array}$ \\
\hline $\begin{array}{l}\text { National coaching } \\
\text { organisations and other } \\
\text { coaching related } \\
\text { organisations }\end{array}$ & $\begin{array}{l}\text { Baltic Coaching Centre; } \\
\text { Riga Coaching School; } \\
\text { Riga Coach Club; Eiro Personāls Ltd } \\
\text { Personības pilnveidošanas centrs; } \\
\text { Franklin Covey ; Talentor }\end{array}$ & $\begin{array}{l}\text { Association of professional coaches in } \\
\text { Lithuania; } \\
\text { Baltijos koučingo centras }\end{array}$ \\
\hline Projects and programs & $\begin{array}{l}\text { Pilot project Career Mentoring and } \\
\text { Coaching, 2010; } \\
\text { JOSEFIN - Joint SME Finance for } \\
\text { Innovation, 2009-2012; } \\
\text { 2014-2016 "Coaches of SMEs: 5POINTS } \\
\text { Trainings"; } \\
\text { International accredited professional } \\
\text { business coaching training program } \\
\text { "Leader as a Coach"Certified training } \\
\text { program "Workplace Coach" }\end{array}$ & $\begin{array}{l}\text { Master degree program "Ugdomasis } \\
\text { vadovavimas / Koucingas" (Coaching) } \\
\text { in Mykolas Romeris university; } \\
\text { Coaching Excellence Club (CEC) in } \\
\text { OVC }\end{array}$ \\
\hline Survey, research, books & $\begin{array}{l}\text { TNS Latvia, } 2011 \\
\text { TNS Latvia, } 2013\end{array}$ & $\begin{array}{l}\text { Coaching Opportunities Evaluation of } \\
\text { Lithuanian Organizations. Consultants' } \\
\text { Survey, 2012; } \\
\text { Practical coaching aspects in } \\
\text { Lithuanian organizations, 2013; } \\
\text { Tomas Misiukonis (2013) Koučingo } \\
\text { technikos,VAGA, }\end{array}$ \\
\hline Events & $\begin{array}{l}\text { Coaching Week } \\
\text { Master classes } \\
\text { Seminars, conferences }\end{array}$ & $\begin{array}{l}\text { Coaching Week } \\
\text { Master classes, } \\
\text { Winter and Summer schools } \\
\text { Seminars, conferences }\end{array}$ \\
\hline
\end{tabular}

(source: authors)

etc. Coaching in organisations is mostly focused on the development of a new style of leadership as well as on the support provided to entrepreneurs to implement their new ideas. International accredited professional business coaching training program "Leader as a Coach" is created for leaders, managers and HRM specialists. The aim of the program is to facilitate development of basic skills of people management in the coaching style. A special annual event Coaching Week has been running for the last few years. Different events such as lectures, workshops, master classes, coaching sessions and activities take place.

\section{Methods}

The paper employs two-step research: content analysis of both coaching definitions extracted from the literature and experts' interview with subsequent comparative analysis of the obtained results. Triangulation of research results was obtained through cross verification from two sources.

The definitions for analysis were drawn from the published articles as well as books relating to coaching. General definitions of coaching, definitions of executive coaching and definitions of coaching in different business contexts were taken for analysis. The articles (Bozer et al. 2013; Moen and Federici 2012; Passmore and Fillery-Travis 2011; Stober 2008) were chosen from the academic peer-reviewed journals including: Coaching: An International Journal of Theory, Research and Practice, Journal of Management Development. In addition, books on coaching (Cox et al. 2011; Cox 2013; 
McCarthy 2014) and the definition accepted by International Coach Federation (ICF) in ICF Code of Ethics were explored as well.

The list of definitions was supplemented by coaching definitions gathered by Hamlin et al. (2008) for their study into 'conceptualizations and definitions of coaching'. The definitions provided by Fournies (1987), Orth et al. (1987), Evered and Selman (1989), Popper and Lipshitz (1992), Mink et al. (1993), Hargrove (1995), Burdett (1998), Clutterbuck (1998), Hudson (1999), Redshaw (2000), Grant (2001, 2006), Peterson (1996), Kampa-Kokesch and Anderson (2001), Parsloe (1995), Grant and Cavanagh (2004), Zeus and Skiffington (2000), Kilburg (2000), Peltier (2001), Orenstein (2002), McCauley and Hezlett (2001), Hall et al. (1999), Caplan (2003), Plunkett et al. (2004), Dingman (2006), Sanders (1996), Hill (1998), Storey (2003), Bacon and Spear (2003), Clegg et al. (2003), Taylor (2007) were taken for the analysis to get a broader view.

In total, 41 definitions of coaching were taken for the analysis. The aim of the analysis is to identify the characteristics of coaching which are frequently used in the definitions and, based on it, identify the distinctive features of coaching.

Two types of coding: open coding and axial hierarchical coding were applied. The aim of open coding is to generate as many codes as possible to identify relevant themes. The aim of axial coding is to generate the interconnections between these themes.

The second stage of the research was the experts' interview. The aim of this stage is to explore the views of practitioners in coaching about a place of coaching in organisations based on their personal opinion and professional experience. The interview contains two meaningful parts and consists of basic 12 questions. The interview questions are developed to capture the essence of coaching in organisational context. Supplementary questions are asked based in the individual experience of the practitioners. The duration of interview is one hour.

Online interviews were conducted from September to December, 2013. For the purposes of the research it was decided to focus on the key informants, i.e. experienced practitioners in coaching, to generate primary data for qualitative analysis. The selection of practitioners was based on the following criteria: participation in the training programme for coaches, work with organisations, and experience in the field of coaching for more than 3 years as well as a genuine desire to contribute to the research. Based on the established criteria, four coaches from Latvia, three coaches from Lithuania, one coach from Poland and one coach from Germany took part in the interview. The experts from Poland and Germany were invited with the aim to trace the tendency of development of the subject matter in the countries that might have influence on the Baltic countries.

All most all respondents have graduated from accredited coach training programmes; among them one interviewee has gained Master's degree in coaching and another one is working to get this degree. All respondents identified that they work at organisational level defining their professional background as an executive coach, organisation leader, HR and training specialist, consultant. The practitioners indicated that their average experience in coaching is $3-5$ years. The coaches were asked to define the industry sectors that used their coaching services and the size of the companies. The analysis of responses shows that the respondents work in different industries and with the companies of different size. The coaches are engaged in Retail and Wholesale, Banking and Finance Services, Information Technology, Manufacturing 
and Production, Education, Health Care. Most coaches identified that they work in the companies of the size from 51 to 250 employees.

\section{Results and discussion}

\section{Addressing research question: How is coaching defined?}

The analysis of 41 selected definitions showed that there is no unified approach to the definition of coaching. Coaching is defined from different perspectives, as a result, not all of the research questions are addressed in each definition. Therefore, a sufficiently large number of definitions ensure the reliability of the results.

More than $40 \%$ of definitions characterize coaching as a process (Fig. 1).

Based on commonly used characteristics, coaching is defined as a regular (KampaKokesch and Anderson 2001; Grant 2006), synergic (Zeus and Skiffington 2000; Storey 2003; Grant 2006; McCarthy 2014), learning and development (Caplan 2003; Cox et al. 2011; Cox 2013), goal-oriented (Hall et al. 1999; Grant 2001, 2006; Grant and Cavanagh 2004) process.

The first question of the experts' survey was about key words what coaches use to define the sense of coaching. Content analysis of the experts' answers identified 21 words that coaches named as key ones. Frequency of words was computed via SQL query to table containing key words from definitions of coaching provided by experts. The word that was used more frequently was the word development. Figure 2 graphically illustrates the results.

The results of the study suggest that by experts' opinion, development characteristic is a key feature of coaching. Coaching was also defined as an art and science to support person or a group of people in exploring and promoting self-awareness that influences people potential and growth.

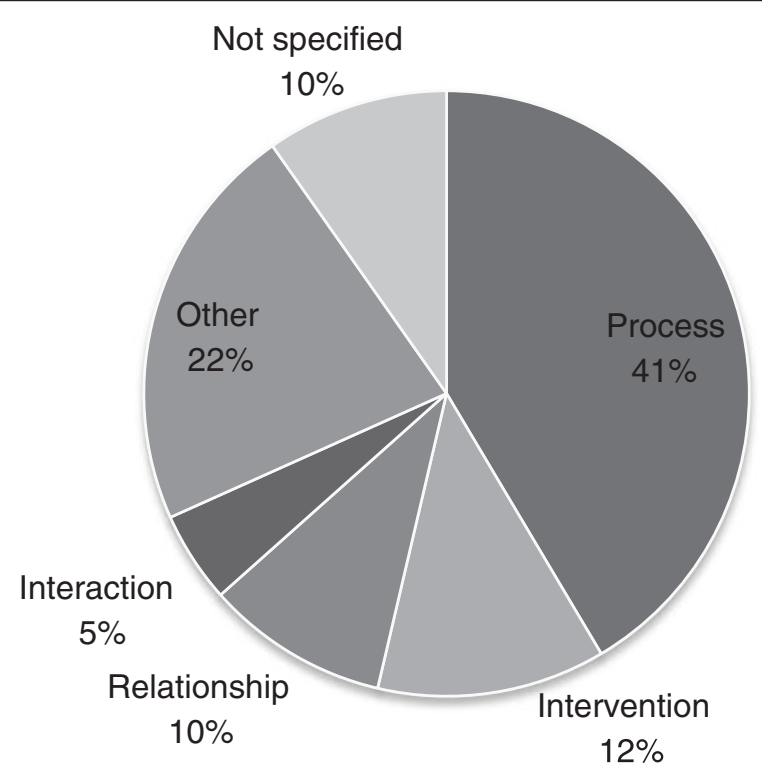

Fig. 1 The analysis of coaching definitions (source: authors) 


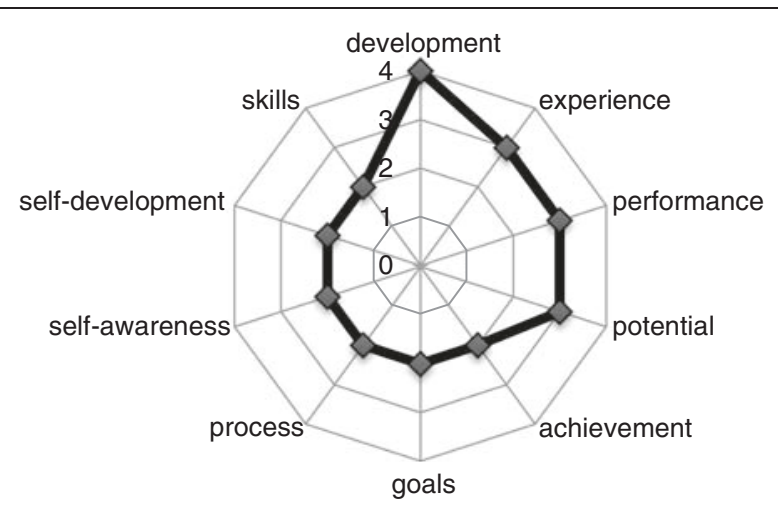

Fig. 2 The key words frequency (source: authors)

\section{Addressing research question 2: What is the aim of coaching?}

Since the emergence of the concept of coaching, the purpose of this practice has been changing. The aim of coaching switched from performance problems (Fournies 1987) to developmental perspective (Cox et al. 2011). Coaching facilitates discovering opportunities (Orth et al. 1987; Hill 1998) and creating 'a culture of development' (Popper and Lipshitz 1992) to enhance performance and efficiency (Orth et al. 1987; Burdett 1998). Mink et al. (1993) understood coaching as the process in which established relationships between coach and clients ease learning. By its nature, coaching can be directive and non-directive (Clutterbuck 1998). Coaching that teaches to generate results (Hargrove 1995) and guides others into enhanced capacity, commitment and self-confidence (Hudson 1999; Redshaw 2000) is mostly run to the directive approach. More recent definitions consider coaching as facilitating activity for self-directed learning and personal growth and change (Grant and Cavanagh 2004; Grant 2006; Peltier 2001; Stober 2008).

Content analysis of coaching definitions reveals the key words that describe the aim of coaching. Under the analysis, coaching is used to improve, to facilitate, to create and to support (Fig. 3).

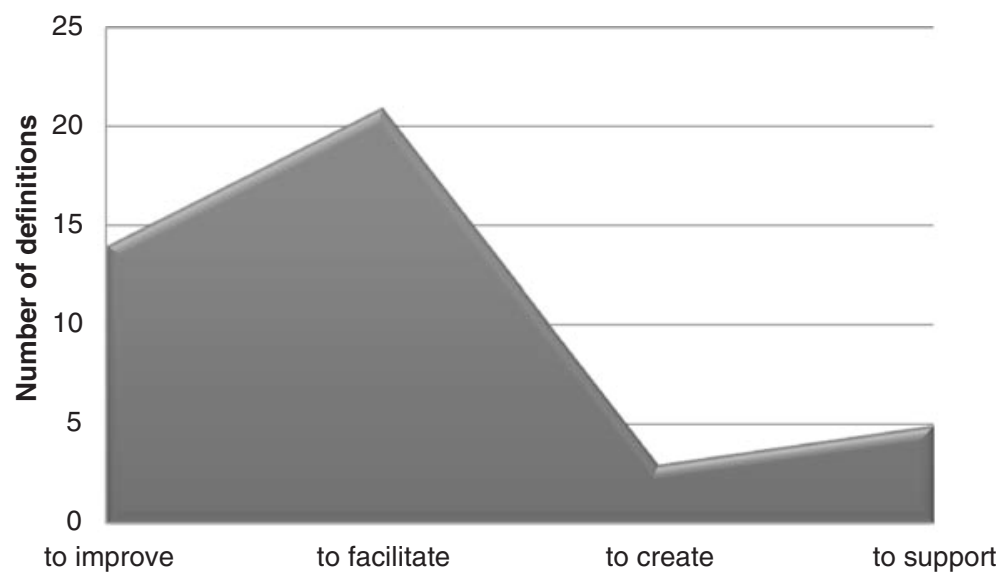

Fig. 3 The analysis of the aims of coaching (source: authors) 
The analysis shows that facilitation is a primary aim of coaching. Coaching facilitates learning and development (Mink et al. 1993; Parsloe 1995) focusing on experiential learning (Hudson 1999; Dingman 2006) and self-directed learning (Grant 2001, 2006; Grant and Cavanagh 2004). Coaching helps increase performance (Grant 2006; Grant and Cavanagh 2004; Kilburg 2000; McCarthy 2014) as well as promote self-awareness (Passmore and Fillery-Travis 2011; Bozer et al. 2013; McCarthy 2014) and personal growth (Grant and Cavanagh 2004; Stober 2008). Coaching enables both people to recognize opportunities to enhance their performance and skills (Orth et al. 1987) and business to find new peculiar solutions and insights (Hill 1998; Bacon and Spear 2003) to achieve sustained change (Peltier 2001; Stober 2008; Cox et al. 2011).

\section{Addressing research question 3: Who are involved in coaching?}

Implemented in organisations coaching is beneficial for both a person and a client's organisation (Fig. 4). Coaching has been referred to as the activity that enables individuals and teams to achieve results (Evered and Selman 1989). Coaching generates client's sustainable behavioural change in working and personal life (Zeus and Skiffington 2000; McCauley and Hezlett 2001; Grant 2001). This positive change may result in enhancing the entire organisation (Peltier 2001).

By experts' opinion, executives or top management should be at the top of the list of those who need coaching. Middle level management and high potential employees are on the next position respectively. The experts were not provided with a list of potential target groups, they mentioned the coaching recipients who need coaching based on their experience and assumption. Almost half of experts consider that coaching should be started from top managers and then gone down. If senior executive does not know what coaching is, does not support it and is afraid that some manipulations are happening or he is implementing different kind of leadership, like pushing, then coaching most probably does not work at lower level. Top managers have to have an opportunity go to the coaching conversation, or "receive a pack of bonuses where coaching should be".

Answering the question"Can coaching be considered as an effective intervention for all people?" coaches mentioned that coaching is more beneficial for people who provide

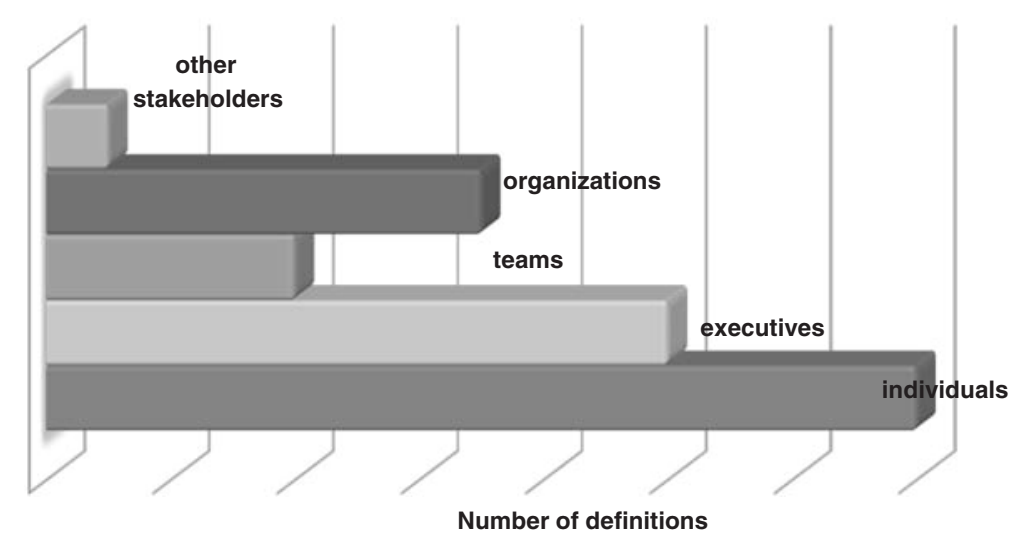

Fig. 4 The parties involved in coaching process (source: authors) 
decisions, first of all it means: top and middle managers. These levels of management generate decisions, and coaching might be really useful in this case because in order to make good decision managers have to be quite competent, they have to know themselves and have to recognize their behavioural patterns. At the same time, the experts highlighted that coaching will be effective if recipients of coaching are ready for coaching. The experts explained that the clients have to be ready to be responsible for themselves and make decisions of their own.

\section{Addressing research question 4: What are expected coaching outcomes?}

Achieved results and personal growth is considered the key expected results (Fig. 5).

Coaching designs atmosphere that empowers employees and organisation to produce results (Evered and Selman 1989; Hargrove 1995; Storey 2003; Bacon and Spear 2003; Dingman 2006). Coaching is expected to contribute to the individual's personal growth and development (Popper and Lipshitz 1992; Kampa-Kokesch and Anderson 2001; Grant and Cavanagh 2004; Grant 2006).

The expert's were asked about key benefits of coaching for individuals and organisations as well as challenges in the implementation of coaching organisations. The benefits and challenges were grouped and summarized in Table 2.

There are a lot of advantages of the coaching use for individual and organisational development. The main thing is that people get new opportunities for development of their self-awareness. That is extremely important for managers especially in the period of organisational change when managers have to often rely on themselves in decisionmaking. As a result of coaching sessions, people are becoming more open and more tolerant to different views, this helps organize relationship within organisation based on trust and respect. This change in relationships very positively reflects on employees' and managers' motivation to support change. Coaching also stimulates the ability to organize individual's thinking process more clearly and more structural. In respect to organisations, coaching provides greater goal clarity, better alignment with the role in organisation that facilitates change in the style of management.

However, the experts focused on possible threats and challenges of coaching as well. As a result of simplified approach to coaching from the side of some organisations, there is a lot of misunderstanding what happens around the coaching. The organisations misunderstand what coaching is and what coaching can do, who should need

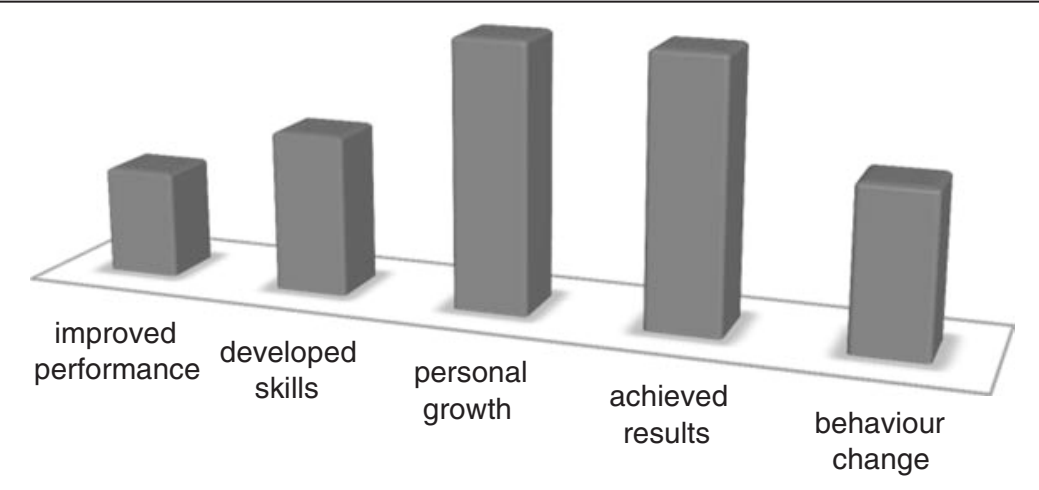

Fig. 5 Expected coaching outcomes (source: authors) 
Table 2 Benefits and challenges of coaching

\begin{tabular}{ll}
\hline Benefits & Threats \\
\hline For individuals & \\
New opportunities for development & Stereotype of coaching \\
People are becoming more open & A lot of simplified interventions in coaching \\
$\begin{array}{l}\text { Development of relationship based on trust } \\
\text { and respect }\end{array}$ & $\begin{array}{c}\text { A lot of misunderstanding what happens around } \\
\text { the coaching }\end{array}$ \\
Ability to organize individually thinking process & Dependence on coach \\
Self-awareness and social awareness & $\begin{array}{l}\text { Sometimes people need training or mentoring } \\
\text { For organisations }\end{array}$ \\
Change in the style of management & $\begin{array}{l}\text { Not possible to start coaching if a client is not } \\
\text { engaged or interested in. }\end{array}$ \\
Greater goal clarity & $\begin{array}{l}\text { Difficult to know exactly how and at what level } \\
\text { coaching is effective. }\end{array}$ \\
Better alignment with the role in the organization & $\begin{array}{l}\text { It is challenge how to look at the coaching in } \\
\text { the systematic way. }\end{array}$ \\
Impact on employees' and managers' motivation & It is difficult to measure the outcomes of coaching \\
\hline (source: authors) &
\end{tabular}

coaching, and what coaching is for. There is also misunderstanding from the other side of those who deliver coaching. Sometimes coaching is wrong intervention and people need training or mentoring that will be more effective than coaching. The dependence on coach is also considered as potential threat. The experts consider that coach is responsible to recognize if the client is dependable.

There are also a lot of challenges in coaching process. The experts argue that it is not possible to start coaching process if the client is not engaged or interested in it. It is difficult to explain how effective coaching can be because coaching is not homogeneous and it is difficult to measure the results of coaching. The other challenge is how to look at coaching in a systematic way when coach gets in touch not only with a client but with client's leader, manager or HR specialist to ensure that coaching engagements are in line in organisational change needs.

\section{Conclusions}

The article explored the essence of coaching in the context of organizational change. Change was considered as a trigger event that stimulates the development of organization. At the same time, change demands from organisations the ability to manage change and to cope with a number of problems. Coaching was studied as a practice that is able to facilitate people to in the period of change to enhance goal achievement, encourage development and support them to tackle change problems. Coaching was also explored as a possible means to promote sustainable organizational change.

Taking into consideration the fact that coaching in EU New Member States is not a widespread practice and is not yet investigated thoroughly, the article was focused on the study of the scope of coaching considering peculiar issues associated with the use of coaching in Latvia and Lithuania. The study attempted to answer the research questions relating to the distinctive features of coaching, the aim of coaching intervention, the parties involved in the process and the expected coaching outcomes. 
The study employed a two-steps approach. Firstly, general definitions of coaching, definitions of executive coaching and definitions of coaching in different business contexts were extracted from the literature and taken for analysis. The aim of the analysis was to identify the characteristics of coaching which are frequently used in the definitions and, based on it, identify the distinctive features of coaching. The second stage of the research was the experts' interview. The aim of the interview was to explore the views of practitioners in coaching about the essence of coaching based on their personal opinion and professional experience.

The analysis of 41 selected definitions showed that there is no unified approach to the definition of coaching. Content analysis of the experts' answer about key words what coaches use to define the sense of coaching identified 21 words that were named as key ones. However, based on commonly used characteristics extracted from definitions, coaching was defined as a regular, synergic, learning and development, goal-oriented process. Development was the world the coaches used more frequently defining coaching. Organizational change demands the ability to develop new knowledge, skills, and patterns of behavior, in this case coaching can be a valuable practice to support individuals of organization in encouraging their self-awareness that influences people potential development and growth.

Content analysis and comparative analysis of coaching definitions revealed the key words that describe the aim of coaching, they are to improve, to facilitate, to create and to support. Facilitation was defined as a primary aim of coaching. To achieve sustainable change, organizations need to be able to recognize opportunities and develop a culture that facilitates change. Coaching as facilitating practice can contribute to individuals' experiential learning and self-directed learning and thus develop their ability to recognize opportunities and to find new business solutions and insights.

Definitions of coaching and experts' answers demonstrated a basic agreement in the implementation of coaching. Both sources considered that coaching is beneficial for a person and for a client's organisation because coaching is referred to as the activity that empowers top leaders and employees to achieve the results.

Achieved results and personal growth was considered as the key expected coaching outcomes. Experts highlighted a lot of advantages of the coaching use for individual and organisational development, among them the opportunity to develop self-awareness. Coaching also can stimulate the ability to organize individual's thinking process more clearly and more structural. In respect to organisations, coaching provides greater goal clarity, better alignment with the role in organisation that facilitates change in the style of management.

At the same time experts mentioned that it is difficult to predict how effective coaching can be because coaching is not homogeneous and it is difficult to measure the results of coaching.

As far as the paper focuses on the investigation of the essence of coaching, it has not reported on the other authors' related investigations, such as the study of the similarities and differences between coaching and other facilitating activities, namely: mentoring, consultancy, counseling, therapy, mediation. In the future, the additional research will need to be conducted to study the relationship of coaching and leadership and to explore the application of the theories for organizational learning to coaching. 


\section{Acknowledgements}

The paper was supported by the project "The Development of Innovation and Entrepreneurship in Latvia in Compliance with the Smart Specialisation Strategy" within the National Research Program 5.2 "Economic Transformation, Smart Growth, Governance and Legal Framework for the State and Society for Sustainable Development - a New Approach to the Creation of a Sustainable Learning Community (EKOSOC-LV)".

Received: 3 September 2015 Accepted: 6 January 2016

R.t.

\section{References}

Allen, S., Smith, J., \& Silva, N. (2013). Leadership style in relation to organizational change and organizational creativity perceptions from nonprofit organizational members. Nonprofit Management \& Leadership, 24(1), 23-42. doi: $10.1002 / \mathrm{nml} .21078$.

Amagoh, F. (2008). Perspectives on organizational change: systems and complexity theories. The Innovation Journal: The Public Sector Innovation Journal, 13(3), 1-14.

Audet, J., \& Couteret, P. (2012). Coaching the entrepreneur: features and success factors. Journal of Small Business and Enterprise Development, 19(3), 515-531. doi:10.1108/14626001211250207.

Bacon, T, Spear, K (2003). Adaptive coaching: The art and practice of a client-centered approach to performance improvement. Palo Alto, CA: Davis-Black

Baron, L., \& Morin, L. (2010). The impact of executive coaching on self-efficacy related to management soft-skills. Leadership \& Organization Development Journal, 37(1), 18-38. doi:10.1108/01437731011010362.

Berg, M., \& Karlsen, J. (2011). An evaluation of management training and coaching. Journal of Workplace Learning, 24(3), 177-199. doi:10.1108/13665621211209267.

Bond, C., \& Seneque, M. (2013). Conceptualizing coaching as an approach to management and organizational development. Journal of Management Development, 32(1), 57-72. doi:10.1108/02621711311287026.

Bozer, G., Sarros, J., \& Santora, J. (2013). The role of coachee characteristics in executive coaching for effective sustainability. Journal of Management Development, 32(3), 277-294. doi:10.1108/02621711311318319.

Burdett, J. (1998). Forty things every manager should know about coaching. Journal of Management Development, 17(2), 142-152. doi:10.1108/02621719810206050.

Burnes, B (2004). Managing change: a strategic approach to organisational dynamics, 4th edition. Harlow, England; New York: Prentice Hall Financial Times.

By, R. (2005). Organisational change management: a critical review. Journal of Change Management, 5(4), 369-380. doi:10.1080/14697010500359250.

Caplan, J (2003). Coaching for the Future: How smart companies use coaching and Mentoring. London: Chartered Institute of Personal and Development.

Clegg, S, Rhodes, C, Kornberger, M (2003). An overview of the business coaching industry in Australia. OVAL Research Working Paper 03-11. Sydney: The Australian Centre for Organizational, Vocational and Adult Learning.

Clutterbuck, D. (1998). Learning alliances tapping into talent. London: Institute of Personnel and Development.

Connor, M., \& Pokora, J. (2007). Coaching and mentoring at work: Developing effective practice (1st ed.). UK: Open University Press.

Corte, V., lavazzi, A., \& D'Andrea, C. (2015). Customer involvement through social media: the cases of some telecommunication firms. Journal of Open Innovation: Technology, Market, and Complexity, 1, 10. doi:10.1186/s40852-015-0011-y.

Cox, E. (2013). Coaching understood. A pragmatic inquiry into the coaching process (1st ed.). London: Sage Publications Ltd.

Cox, E., Bachkirova, T., \& Clutterbuck, D. (2011). The complete handbook of coaching. London: Sage Publications Ltd.

De Haan, E., Culpin, V., \& Curd, J. (2011). Executive coaching in practice: what determines helpfulness for clients of coaching? Personnel Review, 40(1), 24-44. doi:10.1108/00483481111095500.

Dingman, M (2006). Executive coaching: What's the big deal? International Journal of Leadership Studies, 1(2), 2-5.

Evered, R., \& Selman, J. (1989). Coaching and the art of management. Organizational Dynamics, 18(2), 16-32. doi:10.1016/0090-2616(89)90040-5.

Fournies, F. (1987). Coaching for improved work performance. New York: Liberty House.

Garvey, B. (2011). A very short, fairly interesting and reasonably cheap book about coaching and mentoring (1st ed.). London: Sage Publications Ltd.

Garvey, B., Stokes, P., \& Megginson, D. (2009). Coaching and mentoring: Theory and practice. London: Sage Publications Ltd.

Graetz, F., \& Smith, A. (2010). Managing organizational change: Philosophies of change approach. Journal of Change Management, 10(2), 135-154. doi:10.1080/14697011003795602.

Grant, A (2001). Towards a psychology of coaching. Resource document. Coaching Psychology Unit, School of Psychology, University of Sydney. https://www.researchgate.net/profile/Anthony_Grant5/publication/228598134 Towards_a_psychology_of_coaching/links/54c81fa70cf238bb7d0d9949.p. Accessed 14 Jan 2008.

Grant, A. (2006). Solution-focused coaching. In J. Passmore (Ed.), Excellence in coaching: The industry guide (pp. 73-90). London: Kogan Page.

Grant, A. (2014). The efficacy of executive coaching in times of organisational change. Journal of Change Management, 14(2), 258-280. doi:10.1080/14697017.2013.805159.

Grant, A., \& Cavanagh, M. (2004). Toward a profession of coaching: Sixty-five years of progress and challenges for the future. International Journal of Evidence-based Coaching and Mentoring, 2(1), 1-16.

Hall, D, Otazo, K, Hollenbeck, G (1999). Behind closed doors: What really happens in executive coaching. Organizational Dynamics, 27(3), 39-43.

Hamlin, R., Ellinger, A., \& Beattie, R. (2008). The emergent 'coaching industry': awake-up call for HRD professionals. Human Resource Development International, 11(3), 287-305. doi:10.1080/13678860802102534.

Hamlin, R., Ellinger, A., \& Beattie, R. (2009). Toward a profession of coaching? A definitional examination of 'coaching', 'organization development', and 'human resource development'. International Journal of Evidence Based Coaching and Mentoring, 7(1), 13-38. 
Hargrove, R. (1995). Masterful coaching: Extraordinary results by impacting people and the way they think and work together. San Diego, CA: Pfeiffer \& Company.

Hill, P (1998). A school of business coaching. Training and Management Development Methods, 12(4), 411-415.

Hudson, F. M. (1999). The handbook of coaching. San Francisco, CA: Jossey-Bass Publishers.

Ives, Y. (2008). What is 'Coaching'? An exploration of conflicting paradigms. International Journal of Evidence Based Coaching and Mentoring, 6(2), 100-113.

Kampa-Kokesch, S, Anderson, M (2001). Executive coaching: A comprehensive review of the literature. Consulting Psychology Journal: Practice and Research, 53(4), 205-228. doi:10.1037/1061-4087.53.4.205.

Kelley, D., Neck, H. M., O'Connor, G. C., \& Paulson, A. (2005). Corporate entrepreneurship through radical innovation: key organisation and innovative level mechanisms. In Corporate entrepreneurship and venturing (pp. 23-48). US: Springer.

Kempster, S., \& Iszatt-White, M. (2013). Towards co-constructed coaching: Exploring the integration of coaching and co-constructed autoethnography in leadership development. Management Learning, 44(4), 319-336. doi:10.1177/1350507612449959.

Kilburg, R. R. (2000). Executive coaching: Developing managerial wisdom in a world of chaos. Washington, DC: American Psychological Association.

Ladyshewsky, R. (2010). The manager as coach as a driver of organizational development. Leadership \& Organisation Development Journal, 31(4), 292-306. doi:10.1108/01437731011043320.

McCarthy, G (2014). Coaching and Mentoring for Business. London: Sage Publications Ltd.

McCauley, C., \& Hezlett, S. (2001). Individual development in the workplace. In N. Anderson, D. Ones, H. K. Sinangil, \& C. Viswesvaran (Eds.), Handbook of industrial work, and organizational psychology (Vol. 1, pp. 313-335). London: Sage Publications Ltd.

Megginson, D., \& Boydell, T. (1979). A manager's guide to coaching. London: Chartered Institute of Personnel Development.

Mink, O., Owen, K., \& Mink, B. (1993). Developing high-performance people: The art of coaching. Reading, MA: Addison-Wesley Publishing Company, Inc.

Moen, F., \& Federici, R. (2012). The effect from external executive coaching. Coaching: An International Journal of Theory, Research and Practice, 5(2), 113-131. doi:10.1080/17521882.2012.708355.

Orenstein, R (2002). Executive coaching: It's not just about the executive. Journal of Applied Behavioral Science, 38(3), 355-374.

Orth, C., Wilkinson, H., \& Benfari, R. (1987). The manager's role as coach and mentor. Organizational Dynamics, 15(4), 66-74. doi:10.1016/0090-2616(87)90045-3.

Page, N., \& de Haan, E. (2014). Does executive coaching work? Psychologist, 27(8), 582-586.

Parsloe, E (1995). Coaching, mentoring, and assessing: A practical guide to developing competence. London: Kogan Page.

Passmore, J., \& Fillery-Travis, A. (2011). A critical review of executive coaching research: a decade of progress and what's to come. Coaching: An International Journal of Theory, Research and Practice, 4(2), 70-88. doi:10.1080/17521882.2011.596484.

Patra, S., \& Krishna, V. (2015). Globalization of R\&D and open innovation: linkages of foreign R\&D centers in India. Journal of Open Innovation: Technology, Market, and Complexity, 1, 7. doi:10.1186/s40852-015-0008-6.

Peltier, B. (2001). The psychology of executive coaching: Theory and application. New York: Brunner-Routledge.

Peltier, B. (2010). The psychology of executive coaching: Theory and application (2nd ed.). New York: Routledge.

Peterson, D (1996). Executive coaching at work: The art of one-on-one change. Consulting Psychology Journal, 48(2), 78-86.

Plunkett, B, Egan T (2004). Application of psychology-based theoretical approaches to executive coaching: A summary and exploration of potential utility, In Proceedings of the Academy of Human Resource Development, ed. T. Marshall, T, Morris, M. 557-565. Bowling Green, OH: Academy of Human Resource Development.

Popper, M., \& Lipshitz, R. (1992). Coaching on leadership. Leadership \& Organization Development Journal, 13(7), 15-8. doi:10.1108/01437739210022865.

Rank, J., Pace, V., \& Frese, M. (2004). Three avenues for future research on creativity, innovation, and initiative. Applied Psychology: An International Review, 53(4), 518-528. doi:10.1111/j.1464-0597.2004.00185.x.

Redshaw, B. (2000). Do we really understand coaching? How can we make it work better? Industrial and Commercial Training, 32(3), 106-108. doi:10.1108/00197850010371693.

Sanders, D (1996). Eight things you should know about business coaching before contracting for service. Employment Relations Today, 23(2), 67-75.

Spector, B. (2007). Implementing organizational change: theory and practice. Upper Saddle River, NJ: Pearson Education, Inc

Stober, D. (2008). Making it stick: coaching as a tool for organizational change. Coaching: An International Journal of Theory, Research and Practice, 1(1), 71-80. doi:10.1080/17521880801905950.

Stojnov D, Pavlovic J (2010). An invitation to personal construct coaching: From personal construct therapy to personal construct coaching. International Coaching Psychology Review, 5, 129-139.

Storey, M (2003). Bringing head and hear to coaching. Organizational Development Journal, 21(2), 77-81.

Taylor, D (2007). The Naked Coach: Business coaching made simple. Chichester: Capstone Publishing.

The Dublin Declaration on Coaching (2008), Resource document. http://www.gsaec.org/pdf/Dublin_Declaration Coaching_Appendices.pdf. Accessed 15 Mar 2015.

Trenner, L. (2013). Business coaching for information professionals: Why it offers such good value for money in today's economic climate. Business Information Review, 30(1), 27-34. doi:10.1177/0266382113480020.

Vidal-Salazar, M., Ferro'n-VI'Ichez, V., \& Cordo'n-Pozo, E. (2012). Coaching: an effective practice for business competitiveness. Competitiveness Review: An International Business Journal, 22(5), 423-433. doi: $10.1108 / 10595421211266302$.

Zeus, P., \& Skiffington, S. (2000). The complete guide to coaching at work. Roseville, NSW: McGraw-Hill. 